\title{
The effect of an individualize health teaching onpost-operative outcomes for patients undergoing cataract surgery
}

\author{
Azza Mohamed Abdo El-Khamisy, Dr . Shereen Ahmed Ahmed, Dr. Amal Bakr Abo El-Ata
}

Assistant Professor of Medical Surgical Nursing, Portsaid University. Assistant

Professor of Medical Surgical Nursing Portsaid University.

\begin{abstract}
Background: Cataract refers to pacification of lens lead to visual loss. Cataracts can usually be treated with a day-case operation where the cloudy lens is removed and is replaced with an artificial plastic lens Aim: This study aims at evaluating the effect of an individualized health education on postoperative outcomes for patients undergoing cataract surgery. Methods: Quasi-experimental design was utilized for the conducted study. Sitting: The study was carried out in the ophthalmologic, inpatient and outpatient, clinics of the ophthalmologic hospital of Port Saied. Subjects:A convenient sample of eighty six adult patients of cataract from both genders has been taken over a period of six months. Tools: Two tools were used for data collection. Tool (I). A cataract patients, knowledge structured interview which consisted of socio-demographic data, personal habits and knowledge about cataract surgery. Tool (II). Observational checklist which consisted of two parts: part 1.Post-operative cataract outcome. part 2.Snellen eye chart that is used to measure visual acuity. Results: shows that there is a statistically significant difference between total patient knowledge after individualized health teaching and occurrence of complications. Conclusion: Background after applying the individualized health teaching significantly improved patients knowledge, visual acuity, as well as decrease postoperative complications. Recommendations: Further research will be focused on developing an educational booklet and distributing it to all patients who are undergoing cataract surgery in the ophthalmology department and outpatient clinic.
\end{abstract}

Key words: Patients undergoing Cataract surgery, individualized health teaching, postoperative outcomes. 


\section{INTRODUCTION}

Cataract is a clouding or opacity of the lens that leads to gradual painless blurring of vision and eventual loss of sight which is one of the most profound and dreaded of physical disabilities. Opacities of the lens are the leading cause of self declared vision impairment. Mature cataract is a developed cataract that separates easily from the lens capsule. It is one of the few normal physiological changes in the aging process; therefore its incidence increases with age and occurs on both eyes. Developmental cataracts are always congenital and may be hereditary. Acquired cataract may be associated with ocular disease, trauma, systemic disease or aging (Agarwal\& Kumar, 2011).

Over 285 million people in the world are visually impaired, of whom 39 million are blind and 246 million have moderate to severe visual impairment (WHO, 2011). These numbers will rise to 75 million blind and 200 million visually impaired by the year 2020 (WHO, 2010) the main causes of blindness are cataract (47.8\%), glaucoma (12.3\%) and age related macular degeneration (8.7\%). Other causes include corneal opacity $(5.1 \%)$, diabetic retinopathy $(4.8 \%)$, childhood blindness $(3.9 \%)$, trachoma (3.6\%), and onchocerciasis $(0.8 \%)$ (WHO, 2010). While in Upper Egypt major causes of blindness are cataract (60\%) the prevalence is higher in women( 26.5\%) than men (17.2\%)(Mousa et al., 2014).

The majority of cataracts are formed later in life as part of the aging process. Some people develop cataracts earlier than others without any other eye problems. Cataracts can develop as a result of injury, eye disease, systemic problems (such as diabetes), side effects from certain medications, and in some rare cases babies are born with them. Cataracts are not caused or worsened by reading, watching too much television, sewing, or any other visual activity. Limiting your visual activity will not slow down the progression of a cataract(Allen \&Vasavada, 2011)

The cataract can be diagnosed through a comprehensive eye examination which includes patient history, visual acuity measurement, evaluation of the lens, supplemental testing for color vision and glare sensitivity. While there were no clinically proven approaches to prevent cataract but there were simple preventive strategies such as reducing exposure to sunlight through ultraviolet (UV) blocking 
lenses, discontinuing smoking, alcohol, and increasing vitamin E\& C (National Eye Institute, 2013).

Cataract surgery has become one of the most technically advanced area of modern medicine, its types include: Intra capsular Cataract Extraction (ICCE), in which the entire lens capsule was removed with the cryoextractor and now it reserved for cases of phacoanaphylaxis and sublaxation of the lens. Extra capsular Cataract Extraction (ECCE), in which the lens capsule is incised and the lens cortex and nucleus are removed leaving the posterior capsule and lens zonule in place. Small Incision Cataract Surgery (SICS), which results in a good visual outcome. Lastly Phacoemulsification (PHACO), is a process of the lens nucleus fragment ion with ultrasonic vibrations and aspirating the lens material through a double - lumen, irrigation-aspiration system that requires only a small incision. A cataract surgery requires much less time and therefore, can be done comfortably even on a medium risk patient. In a similar manner, the basic nursing requirements to be followed are also the criteria for selection on a day care mode (Black et al., 2014\&Werner, 2010).

An element of risk exists in any surgical procedure and complications (for example, blockage of blood vessels, retinal detachment, corneal swelling, macular swelling, bleeding, and infection) can occur during surgery or in the healing phase after surgery, despite the best care. It is impossible to predict in which patients these complications will occur. No operation of any sort can ever be performed without risk. A very rare complication after cataract surgery, well over $90 \%$ of patients will see significantly better. If patients who are known to have retinal diseases are excluded from this group, the success rate is even higher, approaching 98\%. Your doctor will be discussing with you risks specific to your care prior to surgery.(Thomas et al., 2013).

During The preoperative preparation period, the nurse should determine the patient's basic knowledge about the cataract procedure. As well as any preoperative assessment must assess the patient's ability to maintain their own safe environment, Take the medications on morning of the surgery, leave all jewelry, do not use scented products perfume, aftershave, powder, spray and eye or face make-up Bring their glasses or sunglasses with them and have a responsible adult who arrive them to home(Gogate et al., 2012). 
The nurse plays a significant role in taking care of patients. This role can be classified into immediate post-operative care which includes measuring the vital signs, checking the blood sugar and assessing the level of pain. It also includes giving written instructions to the patients and their families on how to use eye drops and medication, wear glasses or eye shield to protect their eyes from injury, wash the eyelid gently with a piece of cotton and to gradually increase daily physical activity. Not just that, they also have to avoid watching the television, reading when they feel tired, getting water soap in their eyes, carrying heavy objects, and constipation for the first week after the surgery. They should also attend the follow up after a week, and then again after about a month to monitor healing. Contact the doctor immediately if there are any complains of any of the following: Vision loss, the operated eye becomes very painful or swollen, increased eye redness, nausea, vomiting and excessive coughing (Johnson, 2008; Hardy, 2009).

\section{Significance of the Study:}

Cataract is considered as a significant global health problem and represents the most important cause of visual impairment worldwide. Cataract affects individuals in different daily life activities such as driving, undertaking work that requires fine detailing or recognition. Although cataract surgical health teaching program is an important component of ophthalmology, it requires building trusting relationships between patients and their families and health team members. This ensuresthat patients receive appropriate and high quality health teaching from the staff of the hospital to relieve patients' anxiety and dissatisfaction. It also improves visual acuity and controls post-operative complications.

Cataract surgeries are created to cure diseases and to relieve sufferings, but they can also lead to another suffering by causing negative outcomes, Negative outcomes refer to the development of complications that can either impair the patient's visual function or consume resources. (Karaj et al., 2010).

\section{OPERATIONAL DEFINITION:}

\section{Post-operative outcomes:}

Is an improved visual acuity that controls post-operative complications after, 24 hours to 1 month, complications such as retinal detachment, bleeding, and septic infection. 


\section{AIM OF THE STUDY:}

The aim of the study is to evaluate the effect of an individualized health teaching on postoperative outcomes in patients undergoing cataract surgery.

\section{Reassert Hypothesis:}

1. Patients who attend an individualized teaching program exhibit more actual visual function than those who do not attend it.

2. Patients who attend an individualized teaching program experience less complication than those who do not attend it.

3. Patients who attend an individualized teaching program experience less level of anxiety than Patients and their family than those who do not attend it

4. Patients who attend an individualized teaching program experience decrease in the period of recovery and improve rehabilitation than those who do not attend it.

\section{SUBJECTS AND METHODS:}

The design of this study was a quasi experimental design done to evaluate the effect of an individualized health teaching on post-operative outcomes for patients undergoing cataract surgery.

\section{Setting:}

This study was conducted in the ophthalmologic in-patients and ou-tpatients clinics of the ophthalmologic of Port Said hospital.

\section{Subject:}

A convenient sample of (68) patients undergoing cataract surgery randomly assigned during six months from (January to June 2016).

\section{Inclusion criteria:}

- Adult patient from both genders (aged 20- 60 years)

- Alert patient, able to communicate with no speech or listening disorders. 


\section{TOOLS OF DATA COLLECTION:}

Data was collected by using two adapted tools:-

\section{TOOL (I): Cataract patients Knowledge Structured Interview}

It was developed by Elsayed (2012) to assess patients' knowledge related to cataract surgery. It includes two parts:

\section{Part (1):}

It includes socio-demographic characteristics of studied patients, age, sex, education level, occupation, marital status...etc

\section{Part (2):}

It includes personal habits such as (smoking, drinking, watching television, reading and using the computer for long periods), and clinical data as diagnosis, type of surgery, ocular history, present medical history, associated disease, chief complains, and medications pertaining to cataract surgery before the operation either prescribed general, ocular or over the counter medication. This is in addition to source of information related to his /or her disease.

\section{Scoring system:}

In order to calculate cataract patients' knowledge the total grades distributed as the following:

- Knowledge related to meaning of cataract

1 grade

- Knowledge related to risk factors of cataract

11 grades

- Knowledge related to signs \& symptoms of cataract

5 grades

- Knowledge related to types of cataract surgeries

2 grades

- Knowledge related to postoperative cataract complications 10 grades

- Knowledge related postoperative eye care 4 grades

- Knowledge related to administration of eye medications

11 grades

- Knowledge related to postoperative precautions

14 grades

Patients' knowledge score for (8) parts was calculated to be (58). The respondent was given one point for each correct answer and zero point for 
incorrect answer; the score was converted into a percent score. Total score of $60 \%$ and more was considered satisfactory knowledge, while score below 60\% was considered unsatisfactory knowledge, according toElsayed (2012).

TOOL (II): Observational Checklist after cataract surgery.

It was developed byElsayed (2012) to assess post-operative cataract outcomes it includes two parts:

Part (1):

It included follow up visit to assess the presence or absence of post-operative cataract complications after 24 hours post operatively until 1monthpostoperatively such as (endophathalmitis, elevated intraocular pressure, cystoid macularedema, hemorrhage, wound leak, retinal detachment, and opacification of the posterior capsule, iris prolapse, corneal edema, lens decentration, and vision loss.

Part (2):

It includes Snellen's eye chart to assess the best corrected visual acuity postoperatively by visit from First visit before surgery to forth visit after month postsurgery.

\section{METHODS OF STUDY:}

- An official letter was issued from the dean of the faculty of nursing, Port Said University to the directors of ophthalmologic Port Said hospital to obtain their permission to conduct the study.

- To assess the validity of the tools used in the study they had to be translated into Arabic. This translation helped in determining whether the tools achieve the aim and also in making them appropriate, relevant and clear for the jury that consists of nine experts from the medical staff of general surgery and medical-surgical nursing staff, Port Said University.

- An informed consent was obtained from all patients including the right to withdraw from the study after explaining the purpose and importance of this withdrawal. Confidentiality and anonymity of the information were assured by the researcher. 
- A pilot study was conducted on $10 \%$ of patients to test; feasibility and applicability of the tools to be clear and understandable, the final form of the tools were reconstructed and made ready for use.

- Reliability of tools was checked by testing its internal consistency using Alpha Cronbach reliability test. Cataract patients' knowledge interview (0.82), observational checklist (0.78).

- The actual study was conducted through four phases: assessment phase, individualized health teaching development phase, implementation phase and evaluation phase.

\section{Statistical Analysis of Data:}

1. The raw data were coded and transformed into coding sheets. The results were checked. Then, the data were entered into SPSS system files (SPSS package version 18) using personal computer. Output drafts were checked against the revised coded data for typing and spelling mistakes. Finally, analysis and interpretation of data were conducted.

\section{The following statistical measures were used:}

- Descriptive statistics including frequency, distribution, means, and standard deviation were used to describe different characteristics.

- Univariate analyses including: Student t-test and paired t-test were used to test the significance of results of quantitative variables. McNemar test was used to test the significance- of results of qualitative variables.

- The significance of the results was at the $5 \%$ level of significance.

\section{Limitation of the Study}

Usually patients who hadthe best visual acuity, withdrawn after the first or the second visit for follow up. Thus, we were obliged to exclude them from the selected subjects, thus there were an increase in the period of data collection more than the researcher had predicted. 


\section{RESULT:}

Table (1): is the Socio-demographic characteristic of the studied patients undergoing cataract surgery. Regarding the age of more than half of the studied patients $(54.4 \%)$ was in an age group ranged from50 to less than 60 years.

Regarding gender more than half of them were females $(52.9 \%)$ and $(66.2 \%)$ were married .In relation to residence, more than two fifths of them $(64.7 \%)$ were from rural area, (23.5\%) of them had university level education. As regards the job, less than one third of them $(29.4 \%)$ had professional work.

Table (2): shows the relation between the total knowledge of patients before and after individualized health teaching sessions for a period of time from one week to a month post operatively. There is a statistically high and significant difference between patients' total knowledge pre and post individualized health teaching while there is no statistically significant difference between the total knowledge post individualized health teaching and the total knowledge one week after it .However, there is a statistically significant difference between total knowledge pre individualized health teaching and one month after it.

Table (3): shows that there is a statistically significant difference between total Patient knowledge after individualized health teaching and the occurrence of postoperative complications.

Table (4): shows the results of snellen's eye test for studied patients starting from their first visit before cataract surgery to their forth visit (1 month post-surgery). The results of the majority of patients in preoperative period ranged between hand motion (HM), counting fingers (CF) and 6\60 (VA) show that they need surgery because it affects their daily life activities. While in the postoperative period the present results reveal an improvement of visual acuity for all studied patients. Also, there is a statistically high and significant difference between the measurement of visual acuity in the left and right eyes infirst visit before-surgery and the measurement of visual acuity in the left and right eyes in the fourth visit one month post-surgery. 
Table (5): shows that; there is a statistically high and significant difference between the reactions of the right and the left eyes as a response to hand movement in the first visit before-surgery and in the fourth visit one month post-surgery.

Table (1): Socio-demographic characteristics of the studied patients undergoing cataract surgery $(n=68)$

\begin{tabular}{|c|c|c|}
\hline Items & $\begin{array}{l}\text { Frequency } \\
\text { No }\end{array}$ & $\begin{array}{l}\text { Percentage } \\
\%\end{array}$ \\
\hline \multicolumn{3}{|l|}{ Age: } \\
\hline 20- less 30yrs & 8 & 11.8 \\
\hline 30-less than 40yrs & 10 & 14.7 \\
\hline 40 less than 50yrs & 13 & 19.1 \\
\hline $50-60 \mathrm{yrs}$ & 37 & 54.4 \\
\hline \multicolumn{3}{|l|}{ Gender: } \\
\hline Male & 32 & 47.1 \\
\hline Female & 36 & 52.9 \\
\hline \multicolumn{3}{|l|}{ Marital status: } \\
\hline Single & 15 & 22.1 \\
\hline Married & 45 & 66.2 \\
\hline Divorced & 2 & 2.9 \\
\hline Widower & 6 & 8.8 \\
\hline \multicolumn{3}{|l|}{ Education: } \\
\hline University & 9 & 13.2 \\
\hline Intermediate education & 16 & 23.5 \\
\hline Secondary & 0 & 0.0 \\
\hline Primary & 9 & 13.2 \\
\hline Read and right & 13 & 19.1 \\
\hline Illiterate & 21 & 30.9 \\
\hline \multicolumn{3}{|l|}{ Job: } \\
\hline Professional worker & 20 & 29.4 \\
\hline Employee & 18 & 26.5 \\
\hline Manual work & 6 & 8.8 \\
\hline House wife & 16 & 23.5 \\
\hline Retired & 1 & 1.5 \\
\hline does not work & 7 & 10.3 \\
\hline \multicolumn{3}{|l|}{ Residence: } \\
\hline Rural & 44 & 64.7 \\
\hline Urban & 24 & 35.3 \\
\hline
\end{tabular}

Significant at the $\mathrm{p} \leq .05$

McNemar significant qualitative variables 
Table (2): Relation between total patient knowledge after individualized health teaching and occurrence of complication topatient(1 week and 1month )

\begin{tabular}{|c|c|c|c|c|c|c|}
\hline \multirow[t]{3}{*}{ Items } & \multicolumn{4}{|c|}{$\begin{array}{l}\text { Total Patient Knowledge after } \\
\text { individualized health teaching } \\
\text { from 1week }+1 \text { mounth }\end{array}$} & \multirow[t]{3}{*}{$\mathbf{X}^{2}$} & \multirow[t]{3}{*}{ p-value } \\
\hline & \multicolumn{2}{|c|}{ Unsatisfactory } & \multicolumn{2}{|c|}{ Satisfactory } & & \\
\hline & No & $\%$ & No & $\%$ & & \\
\hline \multicolumn{5}{|c|}{ Occurrence of complications } & & \\
\hline Present & 7 & 38.9 & 6 & 12.0 & \multirow{2}{*}{6.189} & \multirow{2}{*}{$.013^{x}$} \\
\hline Not present & 11 & 61.1 & 44 & 88.0 & & \\
\hline Total & 18 & 100.0 & 50 & 100.0 & & \\
\hline
\end{tabular}

Table (3): Relation between total knowledge pre and post during one weekand month post operatively

\begin{tabular}{|c|c|c|c|c|c|c|}
\hline \multirow{3}{*}{ Items } & \multicolumn{4}{|c|}{ Total knowledge post } & \multirow{3}{*}{$\mathbf{X}^{2}$} & \multirow{3}{*}{ p-value } \\
\hline & \multicolumn{2}{|c|}{ Unsatisfactory } & \multicolumn{2}{|c|}{ Satisfactory } & & \\
\hline & No & $\%$ & No & $\%$ & & \\
\hline \multicolumn{7}{|l|}{$\begin{array}{l}\text { Total knowledge pre } \\
\text { individualized health teaching }\end{array}$} \\
\hline Unsatisfactory & 16 & 88.9 & 42 & 84.0 & \multirow{2}{*}{$\begin{array}{l}\text { McNema } \\
\text { r Test }\end{array}$} & \multirow{2}{*}{$.000 * *$} \\
\hline Satisfactory & 2 & 11.1 & 8 & 16.0 & & \\
\hline \multicolumn{7}{|l|}{$\begin{array}{l}\text { Total knowledge 1week post } \\
\text { individualized health teaching }\end{array}$} \\
\hline Unsatisfactory & 10 & 55.6 & 20 & 40.0 & \multirow{2}{*}{1.299} & \multirow{2}{*}{.254} \\
\hline Satisfactory & 8 & 44.4 & 30 & 60.0 & & \\
\hline \multicolumn{7}{|l|}{$\begin{array}{l}\text { Total knowledge1month post } \\
\text { individualized health teaching }\end{array}$} \\
\hline Unsatisfactory & 10 & 55.6 & 15 & 30.0 & \multirow{2}{*}{3.718} & \multirow{2}{*}{$.054 *$} \\
\hline Satisfactory & 8 & 44.4 & 35 & 70.0 & & \\
\hline Total & 18 & 100.0 & 50 & 100.0 & & \\
\hline
\end{tabular}

*Significant at the $\mathrm{p} \leq .05$ 
Table (4): Snellen eye test for studied patients from first visit before cataract surgery to forth visit(1 month post-surgery).

\begin{tabular}{|c|c|c|c|c|c|c|c|c|c|c|c|c|c|c|c|c|c|c|c|c|}
\hline & \multicolumn{4}{|c|}{$\begin{array}{l}\text { First visit before } \\
\text { surgery } \\
\text { (Pre- operative) }\end{array}$} & \multicolumn{4}{|c|}{$\begin{array}{l}\text { Second visit day } \\
\text { post-surgery } \\
\text { (afterlday p.o) }\end{array}$} & \multicolumn{4}{|c|}{$\begin{array}{l}\text { third visit week post- } \\
\text { surgery } \\
\text { (afterlweek } \\
\text { p.o) }\end{array}$} & \multicolumn{4}{|c|}{$\begin{array}{l}\begin{array}{l}\text { forth visit month post- } \\
\text { surgery } \\
\text { (afterlmonth p.o) }\end{array} \\
\end{array}$} & \multicolumn{2}{|l|}{$\begin{array}{l}\begin{array}{l}\text { Lift } \\
\text { eye }\end{array} \\
\end{array}$} & \multicolumn{2}{|c|}{ Right eye } \\
\hline & \multicolumn{2}{|c|}{ Right eye } & \multicolumn{2}{|c|}{ Lift eye } & \multicolumn{2}{|c|}{$\begin{array}{l}\text { Right } \\
\text { eye }\end{array}$} & \multicolumn{2}{|c|}{ Lift eye } & \multicolumn{2}{|c|}{ Right eye } & \multicolumn{2}{|c|}{ Lift eye } & \multicolumn{2}{|c|}{ Right eye } & \multicolumn{2}{|c|}{ Lift eye } & \multirow[t]{2}{*}{$\mathrm{x}^{2}$} & \multirow{2}{*}{\begin{tabular}{|l|} 
p- \\
val \\
ue
\end{tabular}} & \multirow[t]{2}{*}{$\mathrm{X}^{2}$} & \multirow{2}{*}{\begin{tabular}{|l|}
$p-$ \\
value
\end{tabular}} \\
\hline & \begin{tabular}{|l|} 
No \\
\end{tabular} & $\%$ & No & $\%$ & $\begin{array}{l}\text { N } \\
0\end{array}$ & $\%$ & \begin{tabular}{|l|} 
\\
0
\end{tabular} & $\%$ & No & $\%$ & No & $\%$ & \begin{tabular}{|l|} 
No \\
\end{tabular} & $\%$ & No & $\%$ & & & & \\
\hline $6 \backslash 6$ & 19 & 27.9 & 5 & 7.4 & 22 & 32.4 & 5 & 7.4 & 21 & 30.9 & 5 & 7.4 & 25 & 36.8 & 6 & 8.8 & 87.882 & $0.00^{\star}$ & 47.59 & $000^{*}$ \\
\hline 699 & 7 & 10.3 & 32 & \begin{tabular}{|l}
47.1 \\
\end{tabular} & 9 & 13.2 & 27 & 39.7 & 10 & 14.7 & 29 & 42.6 & 24 & 35.3 & 54 & 79.4 & & & & \\
\hline $6 \backslash 12$ & \begin{tabular}{|l|}
1 \\
\end{tabular} & 1.5 & 0 & \begin{tabular}{|l|}
0.0 \\
\end{tabular} & 1 & \begin{tabular}{|l|}
1.5 \\
\end{tabular} & 0 & 0.0 & \begin{tabular}{|l|}
1 \\
\end{tabular} & 1.5 & 1 & \begin{tabular}{|l|}
1.5 \\
\end{tabular} & 12 & $\begin{array}{ll}17.6 \\
\end{array}$ & 7 & 10.3 & & & & \\
\hline $6 \backslash 18$ & 0 & 0.0 & 0 & 0.0 & 0 & 0.0 & 0 & 0.0 & 6 & 8.8 & 7 & 10.3 & 1 & 1.5 & 0 & 0.0 & & & & \\
\hline $6 \backslash 24$ & 0 & 0.0 & 0 & 0.0 & 0 & 0.0 & 2 & 2.9 & 9 & \begin{tabular}{|l}
13.2 \\
\end{tabular} & 18 & 26.5 & 3 & 4.4 & 1 & 1.5 & & & & \\
\hline $6 \backslash 36$ & 0 & 0.0 & 1 & 1.5 & 0 & 0.0 & 3 & 4.4 & 12 & 17.6 & 5 & 7.4 & 3 & 4.4 & 0 & 0.0 & & & & \\
\hline 6160 & 41 & 60.3 & 30 & 44.1 & 36 & 52.9 & 31 & 45.6 & 9 & \begin{tabular}{|l|l}
13.2 \\
\end{tabular} & 3 & \begin{tabular}{|l}
4.4 \\
\end{tabular} & 25 & 36.8 & 0 & 0.0 & & & & \\
\hline $\begin{array}{l}\text { counting } \\
\text { finger : } \\
\text { Don't see } \\
\text { See }\end{array}$ & $\begin{array}{l}36 \\
32\end{array}$ & $\begin{array}{l}52.9 \\
47.1\end{array}$ & $\begin{array}{l}37 \\
31\end{array}$ & \begin{tabular}{|l|}
54.4 \\
45.6
\end{tabular} & $\begin{array}{l}34 \\
34\end{array}$ & $\begin{array}{l}50.0 \\
50.0\end{array}$ & $\begin{array}{l}38 \\
30\end{array}$ & $\begin{array}{l}55.9 \\
44.1\end{array}$ & $\begin{array}{l}18 \\
50\end{array}$ & $\begin{array}{l}26.5 \\
73.5\end{array}$ & $\begin{array}{l}13 \\
55\end{array}$ & $\begin{array}{l}19.1 \\
80.9\end{array}$ & $\begin{array}{l}3 \\
65\end{array}$ & $\begin{array}{l}4.4 \\
95.6\end{array}$ & \begin{tabular}{|l}
4 \\
64
\end{tabular} & \begin{tabular}{|l|l}
5.9 \\
94.1
\end{tabular} & & & & \\
\hline \begin{tabular}{|l|} 
hand \\
motion : \\
Don't \\
react \\
React \\
\end{tabular} & $\begin{array}{l}34 \\
34\end{array}$ & $\begin{array}{l}50.0 \\
50.0\end{array}$ & \begin{tabular}{|l|}
35 \\
33
\end{tabular} & \begin{tabular}{|l}
51. \\
5 \\
48. \\
5 \\
\end{tabular} & $\begin{array}{l}32 \\
36\end{array}$ & $\begin{array}{l}47.1 \\
52.9\end{array}$ & $\begin{array}{l}38 \\
30\end{array}$ & $\begin{array}{l}55.9 \\
44.1\end{array}$ & $\begin{array}{l}18 \\
50\end{array}$ & $\begin{array}{l}26.5 \\
73.5\end{array}$ & $\begin{array}{l}13 \\
55\end{array}$ & $\begin{array}{l}19.1 \\
80.9\end{array}$ & $\begin{array}{l}3 \\
65\end{array}$ & \begin{tabular}{|l|}
4.4 \\
95.6
\end{tabular} & \begin{tabular}{|l|}
5 \\
63
\end{tabular} & \begin{tabular}{|l|}
7.4 \\
92.6
\end{tabular} & & & & \\
\hline
\end{tabular}

Significant at the $\mathrm{p} \leq .05$ 
Table (5): Relation between react right eye hand moving and Lift eye hand moving First visit before-surgery and forth visit month post-surgery.

\begin{tabular}{|c|c|c|c|c|c|c|c|c|c|c|}
\hline \multirow{4}{*}{$\begin{array}{l}\text { Forth visit month } \\
\text { post-surgery }\end{array}$} & \multicolumn{8}{|c|}{ First visit before-surgery } & \multirow{4}{*}{$\mathbf{X}^{2}$} & \multirow{4}{*}{$\begin{array}{l}\text { p- } \\
\text { value }\end{array}$} \\
\hline & \multicolumn{4}{|c|}{ Right eye hand moving } & \multicolumn{4}{|c|}{ Lift eye hand moving } & & \\
\hline & \multicolumn{2}{|c|}{ Don't see } & \multicolumn{2}{|c|}{ See } & \multicolumn{2}{|c|}{ Don't see } & \multicolumn{2}{|c|}{ See } & & \\
\hline & No & $\%$ & No & $\%$ & No & $\%$ & No & $\%$ & & \\
\hline $\begin{array}{l}\text { Right Hand moving: } \\
\text { Don't react }\end{array}$ & 3 & 8.8 & 0 & 0.0 & 2 & 5.7 & 1 & 3.0 & $\begin{array}{l}\text { (X2)1(3.138 } \\
\text { ) }\end{array}$ & .056 \\
\hline React & 31 & 91.2 & 34 & $\begin{array}{l}100 . \\
0\end{array}$ & 33 & 91.7 & 32 & 97.0 & $\left(X^{2}\right) 2.290$ & .590 \\
\hline $\begin{array}{l}\text { Lift Hand moving: } \\
\text { Don't react }\end{array}$ & 4 & 11.8 & 1 & 2.9 & 3 & 8.6 & 2 & 6.1 & McNemar $^{1}$ & $.000^{*}$ \\
\hline React & 30 & 88.2 & 33 & 97.1 & 32 & 91.4 & 31 & 93.9 & $\left(X^{2}\right) 2 \cdot 157$ & .692 \\
\hline Total & 34 & $\begin{array}{l}100 . \\
0\end{array}$ & 34 & $\begin{array}{l}100 . \\
0\end{array}$ & 35 & 100.0 & 33 & $\begin{array}{l}100 . \\
0\end{array}$ & & \\
\hline
\end{tabular}

Significant at the $\mathrm{p} \leq .05$

$\mathrm{X} 2$ )1: significance test between right eye first visit and right eye fourth visit

$\mathrm{X} 2$ )2: significance test between lift eye first visit and left eye fourth visit.

\section{DISCUSSION:}

The current study aimed at evaluating the effect of thehealth individualized teaching on postoperative outcomes for patients undergoing cataract surgery. Regarding Socio-demographic characteristics, the present study revealed that more than half of the studied patients undergoing cataract surgery ranged in their age from50 to less than 60. This finding, that was clarified Nordqvist, (2016), reported that crystalline loss of function, a specific type of protein (crystallins), begins as the eye ages. As the protein loses function small peptides, made of 10 to 15 amino acids, start forming and accelerate cataract formation in the eye.In addition, Hildreth et al (2012)stated that two thirds of the world's blindness is caused by cataract, trachoma, and glaucoma which mostly occur over the age of 40years.

In addition, the current study revealed that the majority of studied patients in the preoperative period had unsatisfactory knowledge $(88.9 \%)$ related to all previously mentioned items of knowledge, while in the postoperative period in the first week 
there was an unsatisfactory improvement of total knowledge; however, after the first month, it was slightly decreased. These findings may be the immediate effect of individualized health teaching i.e the reinforcement of knowledge, teaching one of the members of the patient's family to act as the patient's care giver and the effect of giving every patient a colored booklet as a reminder Elsayed (2012).

As for the effect of individualized health teaching on the presence or absence of postoperative complications, the present finding revealed that there is a statistically significant decrease in the number of patients who had complications after one day, one week and one month post operatively, while the high percentage in patients with corneal edema may be related to manipulation during surgery. This result is explained byYanoff\& Ducker (2012); Kanski (2011) who stated that corneal edema is miscellaneous complications of cataract surgery. Otherwise, the present study revealed that there is a statistically significant relation between patient's knowledge and occurrence of post cataract complications .This finding supported by Elsayed (2012).

Regarding the effect of individualized health teaching on the postoperative best corrected visual acuity, the present study revealed that the majority of patients in the preoperative period ranged between hand motion (HM), counting finger (CF) and 6/60(VA) and this ranges requires surgery because it affects patients'daily life activities. This finding is accorded with Tabin et al. (2013) who stated that cataract surgery is required when VA below 20/60 as well as Long (2000) who stated that surgery is required when patients feel visually handicapped. Also, the present findings revealed statistically significant improvement of visual acuity for all patients comparing with the pre-operative period; most of them move from ...6/18 to ...6/18. These findings may partially reflect the effectiveness of the individualized health teaching on the visual acuity after one month postoperatively. 


\section{CONCLUSION:}

It can be concluded that the results of this study clarify that using the individualized health teaching instantly after cataract surgery could be effective in improving postoperative patient's knowledge and visual acuity as well as decreasing postoperative complications. Otherwise, there is a statistically significant relation found between patients' knowledge post cataract surgery and their job. Also there is a statistically significant relation between patient's knowledge and the occurrence of post cataract complications.

\section{RECOMMENDATIONS}

\section{A- Recommendation for the Patients:}

1- The developed booklet should be distributed to all patients undergoing cataract surgery in the ophthalmology department and outpatient clinic.

2-Postoperative cataract care and teaching about postoperative precautions and postoperative warning signs should be provided for all patients undergoing cataract surgery by nurses in the preoperative period.

3- Family members should be well instructed about eye care and safe administration of eye medications to help patient follow the instructions in order to improve patient outcomes.

\section{B-Recommendation for Administrator:}

1-An administrator should plan for periodically patient-teaching programs about cataract and its management as one of the hospital's policies.

\section{C-Recommendation for Further Research:}

1-The effect of an in-service training program on patients knowledge and performance related to postoperative care for ophthalmic patients in another geographical area on larger scale for generalization. 


\section{REFERENCES:}

Agarwal, A. and Kumar, D. (2011): Cost-effectiveness of cataract surgery. CurrOpinOphthalmol. 22(1):15-18.

Allen,D.andVasavada,A.Jul(2011). "Cataractandsurgeryforcataract.".BMJ333(7559):1 28-32.doi:10.1136/bmj.333.7559.128. PMID 16840470

American Academy of Ophthalmology (2011): Cataract surgery. Retrieved available at:http://www.geteyesmart.org/eyesmart/diseases/cataract-surgery.cfm.Accessedin $22 / 5 / 2016$.

Black, N., Browne, J., van der Meulen, J., Jamieson, L., Copley, L. and Lewsey, J. (2014): Is there over utilization of cataract surgery in England? Br J Ophthalmol, 93: 13-7.

Elsayed, H. (2012): The Effect of Individualized Teaching on Postoperative for

Patients Undergoing Cataract Surgery, Unpublished master thesis, Faculty of Nursing, University of Alexandria, pp: 1-5.

Gogate, P., Deshpande, M. and Nirmalan, P.(2012) : Why do phacoemulsification? Manual small-incision cataract surgery is almost as effective, but less expensive. Ophthalmology., 114(5):965- 68.

Hildreth, C., Burke, A. and Glass, R. (2012): Cataract. The journal of the American Medical Association; 301 (19):2060.

Johnsion, J. (2012): Handbook of Medical Surgical Nursing, $11^{\text {th }}$ ed., Wilkins \& Philadelphia Lippincott Williams. P.P 245-6.

Kanski, J. (2011): Clinical ophthalmology a systemic approach. 6th ed. Philadelphia: Elsevier Company ,P.p.361. 
Kara, J.N., Sirtoli, M., Santhiago, M., Parede T. and Espíndola, R. (2010): Phacoemulsification versus extra capsular extraction: governmental costs. Clinics (Sao Paulo); 65(4):357-361.

Lang, G. (2000): Ophthalmology a short textbook, New York: Stuttgart thieme Company: 37 (2): 79-86.

Mousa, A., Courtright, P., Kazanjian, A. and Bassett, K. (2014): Prevalence of visual impairment and blindness in Upper Egypt: a gender-based perspective. Ophthalmic Epidemiol; 21(3):190-6.

National Eye Institute (2013): Facts about cataract. Retrieved available: https:// nei.nih.gov/health/cataract/cataract_facts. Accessed in 25/7/2016.

Nordqvist, C. (2016): Cataracts: causes, symptoms and treatments, Retrieved available:http://www.medicalnewstoday.com/articles/157510.php.Accessed in $1 / 10 / 2016$.

Tabin, G., Chen, M. and Espandarl, L. (2013: Cataract surgery for the developing world current opinion in ophthalmology .California: Lippincott Williams \&Wilkins Company, 19 (1):55-9

Thomas, A., Thomas, J. and Grand, M. (2013):Lence and cataract, United States of America, American Academy of Ophthalmolog, 40(3): 66-7.

World Health Organization(2010):Global Data on Visual Impairments, Retrieved available http://www.who.int/blindness/GLOBALDATA-. Accessed in 1/10/2016.

Yanoff M. and Duker J. (2012): Ophthalmology.2nded . Saint .Louis: Mosby Company:P.p. 270. 


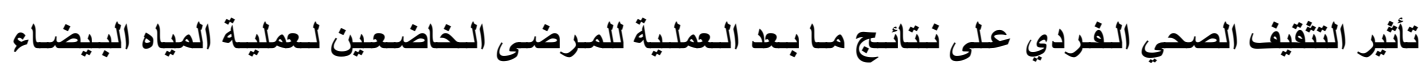
بالـعين

\section{عزة محمد عبد الخميسى ، شيرين أحمد قلاوة ، أمل بكر أبو العطا}

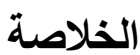

المياه البيضاء هي عتامه فى العدسه تؤدي إلى فقدان البصر. و عادة تتم المعالجة بعمليه يوم واحد تتم فيها إز الة المياه

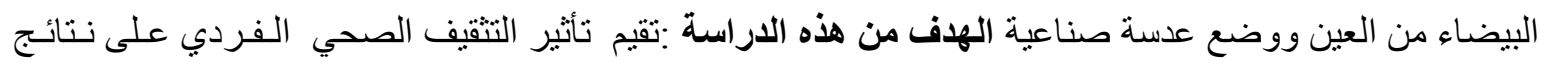
ما بعد العملية للمـرضـى الخاضـعين لعملـية المياة البيضاء بالعين.وتم استخدام التصميم شبه التجريبي لإتمام هذه الدر اسة، التي نفذت في القسم الداخلي و العيادة الخارجية فى مستشفى الرمد ببورسعيد. وقد كانت عينة البحث (68) من البالغين قادرين على التواصل من كلا الجنسين الخاضعين لجر احه المياه البيضاء فى خلال ستة اشهر ــ وتم

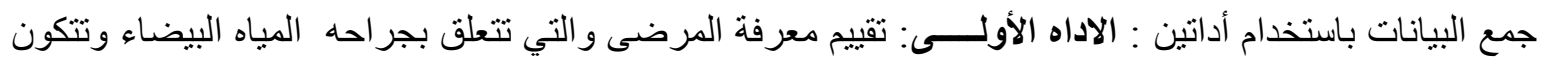
من جزأينالـجـزء الأول: البيانات الاجتماعية والديموجر افية للمريض مثل النوع، السن، الحالة الاجتماعية ،

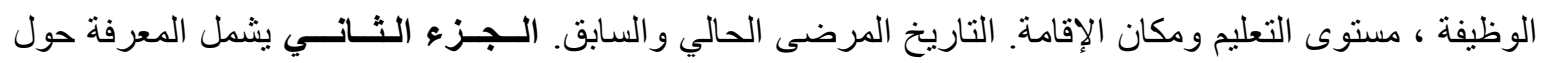

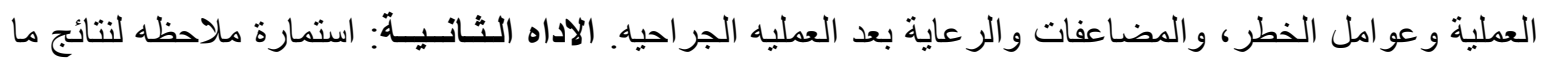
بعد العملية وتتكون من جز أين الــــزءء الأول: تقييم وجود أوعدم وجود مضاعفات للعملية مثل: انفصال الثبكية ؛

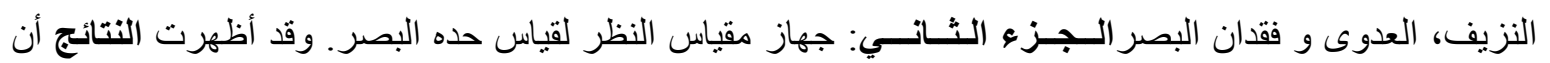
هناك فروق ذات دلالة إحصائية بين المعلومات الكليه للمرضى بعد التثقيف الصحي الفـردي وحدوث المضاعفات.

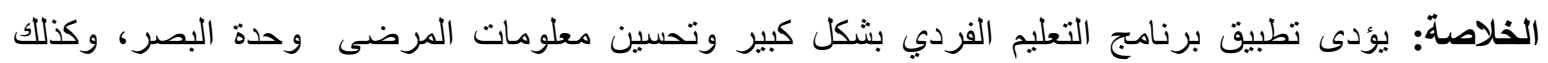
انخفاض مضاعفات ما بعد الجراحة. التوصيات: توزيع الكتيب الملون على المرضى الخاضعين لعمليه المياه البيضاء فى مشتشفيات الرمد فى الاقسام الداخلبية والعياده الخارجيه

الكلمـات المرشدة: التثقيف الصحى الفـردي، نتائج بعد العملية ،المرضى الـخاضـعين لـعلية المياه البيضـاء بالعين 